\title{
KEY FACTORS FOR SUCCESSFUL IMPLEMENTATION OF ERP SYSTEMS
}

\author{
Nebojsa M. Denic, Vuk Vujovic, Vesna Stevanovic, Boban Spasic
}

Original scientific paper

This meticulous research presents methodological aspects of key factors influencing the implementation and introduction of modern information systems, with special emphasis on the implementation of integrated comprehensive ERP system in enterprises in the region. The aim of the work stems directly from the research subject itself and the presentation of the analysis of the ERP systems implementation, through the study of relevant scientific literature and conducted research examples in practice on a representative sample of enterprises, varying in type of activity and ownership structure. The results of this study can serve as material for everyone involved in this current topic, and for those who decide to implement modern integrated ERP solutions to their business, and who want to expand their knowledge respectively.

Keywords: ERP system; implementation; key factors; project

Ključni faktori uspjeha implementacije ERP sustava

Izvorni znanstveni članak U ovom studioznom istraživačkom radu predstavljeni su metodološki aspekti ključnih utjecajnih faktora implementacije i uvođenja suvremenih informacijskih sustava, s posebnim akcentom na implementaciju integriranih sveobuhvatnih ERP sustava u poduzećima u okruženju. Cilj rada izravno proistječe iz predmeta rada i prikaza analize implementacija ERP sustava, kroz istraživanje relevantne znanstvene literature i provedenih istraživanja primjera u praksi na reprezentativnom uzorku poduzeća, različitih po vrsti djelatnosti i vlasničkoj strukturi. Dobiveni rezultati istraživanja ovog rada mogu poslužiti i kao gradivo svima koji se bave ovom aktualnom tematikom, i koji se odlučuju za implementaciju suvremenih integriranih ERP rješenja u svoja poduzeća, i s tim u vezi žele proširiti svoja saznanja.

Ključne riječi: ERP sustav; implementacija; ključni faktori; projekt

\section{Introduction}

Flexibility and rapid responses to all the turbulent changes in the increasingly open and competitive global market are the characteristics of business systems and enterprises operating in the conditions of the current global economic crisis [1]. Especially, in the global competition environment, enterprises have to focus on their Information Systems (IS) performance to have a competitive advantage; implementing an ERP system and improving the effectiveness of the system is the only way [2].

The implementation of enterprise systems, such as enterprise resource planning (ERP) systems, alters business processes and associated workflows, and introduces new software applications that employees must use [3].

Although information technology (IT) has been generally viewed as an effective information processing tool that enables firms to better cope with uncertainty, thus holding the potential to mitigate firm performance volatility, evidence to support this view is lacking in the literature [4]. ICT applications help firms to streamline business operations, enhance business flexibility, integrate functionalities and improve information flow [5]. Access to information in a short time can greatly help businesses and business systems, better customer service, raising the standard of quality, and predicting the market. For all of these assumptions ERP system is a key factor in creating competitive advantages [6]. A successful ERP implementation project brings many benefits to an organization [7]. It can also shorten production cycles, improve customer services, increase the accuracy of demanded forecasts, and reduce expenses from operating expenses [8]. Although some authors believe that ERP systems are adequate only for huge companies and business systems, practical examples and an increasing number of studies suggest that this is not true [9]. Small and medium-sized enterprises, in which we include those with $\$ 50$ to $\$ 500$ million per year, represent the largest market growth for companies producing ERP systems. The use and applicability of ERP systems is extremely high. Today, ERP systems with their universal functions find more users, especially among small, medium and large companies and are used in almost every manufacturing and service businesses [10].

ERP system (an acronym of Enterprise Resource Planning) and integrated business information system is a software system that integrates core business processes in the enterprise such as production, distribution, finance, one accounting into a single whole [11]. ERP is a system through which it is possible on the one hand to manage all the human and material resources, and on the other, to plan, develop and monitor business processes and procedures [12]. The primary benefits of implementation of ERP include: the elimination of inefficient or nonupdated systems, facilitating the adaptation of improved work processes, improved access to information for operational decision-making, etc. [13]. Disadvantages include: the time and cost of bringing ERP system in working condition, problems of compatibility with other existing systems, and a substantial risk if we have only one seller.

\section{Critical success factors characteristics}

The success of the introduction and implementation of the ERP system determines the appropriate critical success factors CSF [14]. Many researchers address the key success factors in implementing ERP systems [15]. One of the characteristic approaches, presented by Shaul $\&$ Tauber, in Towards a More Holistic Approach to the 
Study of Enterprise Systems 42013 [16]. Shaul \& Tauber (2013) point out that most of the identified CSFs are not industry specific and emphasize the need for research on identification of CFSs specific to industry sectors [16]. They, Shaul \& Tauber, (2012) have shown that small and medium enterprises face much greater constraints in terms of resources as compared to large organizations [17]. Ghosh \& Skibniewski (2010) also argue for adapting a complexity perspective in enterprise systems implementation projects [18]. However, Grabski et al. (2011) lament over the fact that while the literature on enterprise systems has dealt with issues such as efficiency, effectiveness, and business performance, there is a relative lack of attention given to the social context [19]. Literature suggests that the number of CSF is relatively large, and is divided into four perspectives: strategic, tactical, organizational and technological perspective [20]. Koh et al. (2011) identify two sets of CSFs: for inter-organization enterprise systems - CSFs which apply to traditional intra-organization enterprise systems and which apply to inter-organization enterprise systems as well, and CSFs that are tailored to the new needs for successful inter-organization enterprise systems implementation [21]. The approach can be used to identify the root causes of ERP system implementation usage failure and quantify the impact of critical component failures or critical risk events in the implementation process [22]. An important aspect is that most of these factors can be considered "classic", because they are not specific to individual ERP implementation [23]. However, given the complexity of these projects, each factor "takes on greater significance." Analysis of the scientific literature on CSF indicates that as the most important factor of management support in ERP implementation, followed by management of organizational change [24]. These CSF have almost nothing to do with technology and almost all are related to people and processes, due to the efforts that should be undertaken by the entire organization in a project of this nature. Research literature indicates that most of the CSF may be regarded as a crucial factor [25]. There is a strong relationship between ERP success and software selection. It is very important to choose the right ERP software [21]. Tab. 1 provides an overview of the key success factors in introducing and implementing ERP systems in companies most often mentioned in the relevant scientific literature and research studies [26].

Table 1 Critical Success Factors Mentioned in the Literature [26]

\begin{tabular}{|c|c|c|c|c|c|c|c|c|c|c|}
\hline & Critical Success Factors (CSF's) & $\mathrm{a}$ & $\mathrm{b}$ & $\mathrm{c}$ & $\mathrm{d}$ & e & $\mathrm{f}$ & $\mathrm{g}$ & $\mathrm{h}$ & $\mathrm{i}$ \\
\hline 1 & Appropriate business and IT legacy systems & & & & $\mathrm{X}$ & $\mathrm{X}$ & & & $\mathrm{X}$ & $\mathrm{X}$ \\
\hline 2 & Architecture Choices & $\mathrm{X}$ & & & $\mathrm{X}$ & $\mathrm{X}$ & & & $\mathrm{X}$ & \\
\hline 3 & Business Plan \& Vision & & $\mathrm{X}$ & $\mathrm{X}$ & $\mathrm{X}$ & $\mathrm{X}$ & & & $\mathrm{X}$ & $\mathrm{X}$ \\
\hline 4 & Business Process Reengineering & $\mathrm{X}$ & $\mathrm{X}$ & & $\mathrm{X}$ & $\mathrm{X}$ & & $\mathrm{X}$ & $\mathrm{X}$ & \\
\hline 5 & Careful package selection & $\mathrm{X}$ & & & & $\mathrm{X}$ & $\mathrm{X}$ & $\mathrm{X}$ & & \\
\hline 6 & Change Readiness \& Culture & $\mathrm{X}$ & $\mathrm{X}$ & $\mathrm{X}$ & $\mathrm{X}$ & $\mathrm{X}$ & & $\mathrm{X}$ & $\mathrm{X}$ & \\
\hline 7 & Clear Goals \& Objective & $\mathrm{X}$ & & & & $\mathrm{X}$ & $\mathrm{X}$ & & & \\
\hline 8 & Communication & $\mathrm{X}$ & & $\mathrm{X}$ & $\mathrm{X}$ & $\mathrm{X}$ & $\mathrm{X}$ & & $\mathrm{X}$ & $\mathrm{X}$ \\
\hline 9 & Data analysis \& conversion & $\mathrm{X}$ & & & & & & $\mathrm{X}$ & & \\
\hline 10 & Education on new business processes & $\mathrm{X}$ & & & & $\mathrm{X}$ & & & & $\mathrm{X}$ \\
\hline 11 & Empowered decision makers & & & & & $\mathrm{X}$ & & & & \\
\hline 12 & Learning competency & $\mathrm{X}$ & $\mathrm{X}$ & & & & & & & \\
\hline 13 & Management of expectations & $\mathrm{X}$ & & & & & $\mathrm{X}$ & & & \\
\hline 14 & Minimal customization & $\mathrm{X}$ & & & & $\mathrm{X}$ & & & & \\
\hline 15 & Monitoring and evaluation of performance & & & & $\mathrm{X}$ & & & & $\mathrm{X}$ & \\
\hline 16 & Organizational Trust between partners & & & & & $\mathrm{X}$ & $\mathrm{X}$ & & & \\
\hline 17 & Partnership with vendor & $\mathrm{X}$ & & & & & & & & \\
\hline 18 & Project champion & $\mathrm{X}$ & & & $\mathrm{X}$ & $\mathrm{X}$ & $\mathrm{X}$ & & $\mathrm{X}$ & \\
\hline 19 & Project management & $\mathrm{X}$ & $\mathrm{X}$ & $\mathrm{X}$ & $\mathrm{X}$ & $\mathrm{X}$ & $\mathrm{X}$ & $\mathrm{X}$ & $\mathrm{X}$ & $\mathrm{X}$ \\
\hline 20 & Strategic IT Planning & & $\mathrm{X}$ & & & $\mathrm{X}$ & & & & $\mathrm{X}$ \\
\hline 21 & Teamwork \& Composition & $\mathrm{X}$ & $\mathrm{X}$ & & $\mathrm{X}$ & $\mathrm{X}$ & $\mathrm{X}$ & $\mathrm{X}$ & & $\mathrm{X}$ \\
\hline 22 & Top management support & $\mathrm{X}$ & $\mathrm{X}$ & $\mathrm{X}$ & $\mathrm{X}$ & $\mathrm{X}$ & $\mathrm{X}$ & $\mathrm{X}$ & $\mathrm{X}$ & $\mathrm{X}$ \\
\hline 23 & Use of consultants & $\mathrm{X}$ & & & & $\mathrm{X}$ & & & & \\
\hline 24 & Use of steering committee & $\mathrm{X}$ & & & & & & & & \\
\hline 25 & Use of vendors' tools & $\mathrm{X}$ & & & & & & & & \\
\hline 26 & User training and education & $\mathrm{X}$ & $\mathrm{X}$ & $\mathrm{X}$ & & $\mathrm{X}$ & & $\mathrm{X}$ & & \\
\hline 27 & Vendor support & $\mathrm{X}$ & & & & & $\mathrm{X}$ & $\mathrm{X}$ & & $\mathrm{X}$ \\
\hline
\end{tabular}

Legend: Studies: a - Somers \& Nelson, (2001); b - Stratman \& Roth, (2002); c - Al-Mudimigh, Zairi \& Al-Mashari, (2001); d - Nah, Zuckweiler \& Lau, (2003); e - Esteves, Sousa, Pastor \& Collado, 2000; f - Akkermans \& Helden, (2002); g - Zhang, Lee, Zhang \& Banerjee, (2002); h - Nah \& Lau, 2001; i Holland, Light \& Gibson, (1999)

\section{Research of CSF in implementation of an ERP system in a company}

In Serbia and in the region recently more and more companies are opting for the introduction of ERP systems in order to increase business performance of its core business functions, such as manufacturing, purchasing, preparing and processing purchase orders, etc. [27].

Anyone who understands the complexity of operating systems, estimates that the introduction of comprehensive and fully integrated systems such as ERP systems is a very demanding job. Tab. 2 presents companies that have been the subject of the research that suggests that in the 
analysed companies, nonetheless, people were largely unprepared and did not understand how such a complicated job can easily be applied to the introduction of such a system. Project introduction and implementation of the ERP system is an extreme challenge and requires an enormous amount of resources, the best IS people, and a lot of management support. Failed ERP installation is more often the result of problems in the implementation, than of the problems in the software. And when there are problems with the implementation of ERP systems, they can be expensive. In most of the examples of studied companies, unfortunately, opinion is wrongly prevailed that the operations of the company become successful as soon as the company replaces the old information system with a modern system that is based on the modern ICT [28]. Therefore, the majority of enterprises around the world now use ERP systems. For example, according to a survey conducted in Germany from 2010 to 2011, ERP systems are used in more than $92 \%$ of all German industrial enterprises [10]. Fig. 1 shows a graphical representation of the examined companies by number of employees.

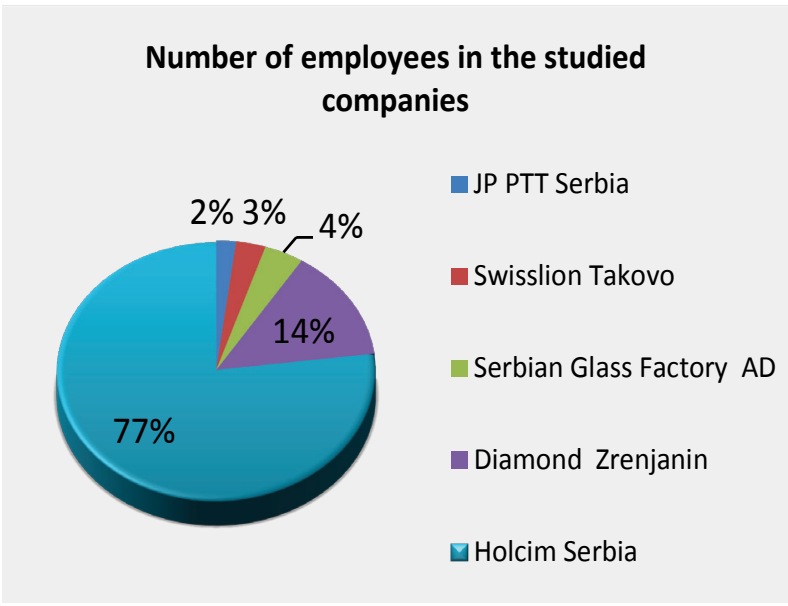

Figure 1 Percentage of employees in the investigated companies in the country (according to the research survey) [28]

Table 2 The companies that participated in the survey (according to a research survey) [28]

\begin{tabular}{|l|c|c|c|c|}
\hline \multicolumn{1}{|c|}{ Company Name } & Type of business & In business & $\begin{array}{c}\text { Number of } \\
\text { Employees }\end{array}$ & web site \\
\hline Serbian Glass Factory AD & Glass industry & 105 & 870 & www.srpskafabrikastakla.com \\
\hline Swisslion Takovo & Confectionery & 17 & 2762 & www.swisslion-takovo.com \\
\hline Holcim Serbia & $\begin{array}{c}\text { Manufacture of cement, aggregates } \\
\text { and ready-mixed concrete }\end{array}$ & 135 & 334 & www.holcim.rs \\
\hline JP PTT Serbia & Postal services, e-commerce, Internet & 174 & 15336 & www.posta.rs \\
\hline Diamond Zrenjanin & Food industry & 76 & 585 & www.dijamant.rs \\
\hline
\end{tabular}

Companies and business systems in the country and the region, now in the new circumstances and conditions, are encountering a harsh reality: prediction, retaliation and response to the increasing demands to the market or to fail [27]. The development of information and communication technologies (ICTs) and their use in company management finds companies of Serbia and the region completely unprepared. When the project introduction and implementation of ERP systems is taking place, most of the companies opt for this option without having done a thorough analysis and re-engineering business processes, which inevitably leads to the failure of implementation of ERP solutions [29]. The cause of this is easily found in the cost of such a project, because the majority of employees in companies see it as a huge financial bite. In addition, they overlook non-financial indicators and long-term objectives and benefits of introducing a new business information system based on the complete operation reconstruction [30]. The following Tab. 3 gives the expectations of implementing SAP ERP solutions.

Table 3 Expectations of implementing SAP ERP solutions (according to a research survey) [28]

\begin{tabular}{|l|l|}
\hline \multicolumn{1}{|c|}{ Company Name } & \multicolumn{1}{c|}{ Expectations of project implementation } \\
\hline Serbian Glass Factory AD & The introduction of new business processes and modernization of business integration. \\
\hline Swisslion Takovo & Improved company management. \\
\hline Holcim Serbia & Integration with corporate headquarters \\
\hline JP PTT Serbia & Establishment of infrastructure technology, improving the management of the Post of Serbia. \\
\hline Diamond Zrenjanin & Implementation on time and improved business performance. \\
\hline
\end{tabular}

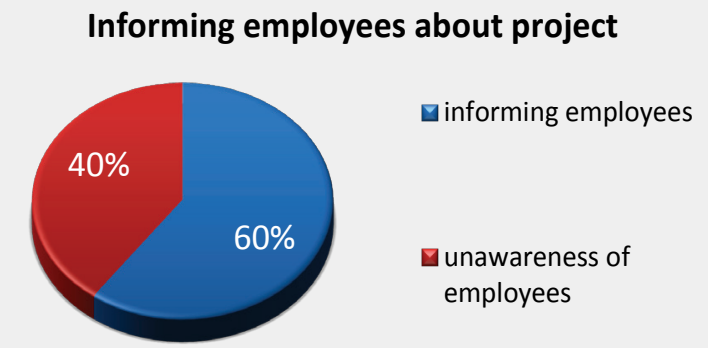

Figure 2 Percentage of informed employees about the ERP project in Serbia (according to the research survey) [28]
The most prominent problem in the companies in which the research was conducted was a lack of attention in the optimization process. The reason is very simple, and yet many times overlooked: no matter how much the technology itself is effective, it can help the company in achieving its business objectives if business processes are not coordinated carefully. Thus, business processes need to be improved, it should be decided which one will be changed, which one might be out, and then apply information technology. It is not an easy task, and in order to successfully achieve it an important thing is effective communication among everyone involved in the establishment of the ERP system. There is often very 
inefficient communication between the parties involved, which is the cause of a large number of difficulties.

Fig. 2 shows the percentage of awareness of employees before deciding on the implementation of ERP solutions.

Another problem that arises is associated with the management of the company, which is running the implementation project of ERP solutions [31]. The problem is related to the management of the company that does not recognize mentioned software solutions in a sufficient and necessary extent. On the other hand, the management is unprepared for the cooperation and involvement into the project of implementations of ERP systems. Research has indicated that there is something else already taking place, the management leaves guiding of the implementation of the enterprise to the IT sector. So they ignore the importance of renewal of business processes and in this respect do not provide sufficient support for the necessary changes. Before the company decides to purchase a new ERP system it is necessary to analyse the existing and plan the future business strategy through the operation of business processes [58]. Studies have shown that almost all of the problems have been identified on the business side, technology mainly represents less of a problem. The conclusion is that tracking business requirements often makes the difference between successful and unsuccessful implementation of the ERP system. And that is exactly what the process approach offers. The causes of the above problems can be various, we will mention just a few:

- Not understanding the significance of previous process improvement,

- Lack of knowledge of their own business processes and their correlation,

- Poor support of top management,

- The project was initiated by the IT department that had no power to include important people from other departments.

Results suggest that the categorized list of ERP training best practices can be used to better understand training activities in ERP implementation projects [32]. Furthermore, the results reveal that the company size and location have an impact on the relevance of training best practices [32].

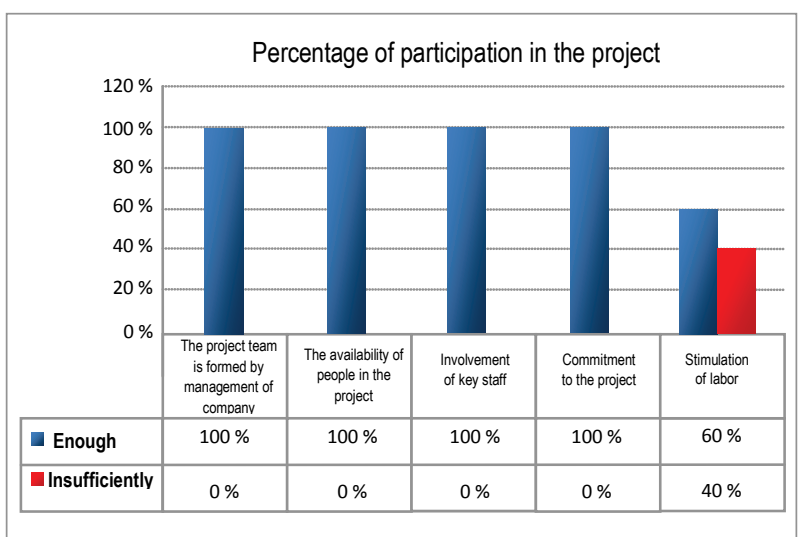

Figure 3 Percentage of participation of involvement, commitment and stimulating the work of a project in the country (according to the research survey) [28]
Fig. 3 shows the percentage share of involvement, commitment and stimulating work of a project in Serbia, which emphasizes that the importance of the support of the top leadership means the support to the project in terms of delegating resources to the project, which are necessary for the successful implementation of ERP solutions. That is why it is important for management to understand the importance of the project and its success. It is equally important for all the members of the Company's management to actively participate in the project implementation of ERP solutions. Acceptability by users means that customers are satisfied with the proposed solutions, that it is really a solution that will serve as an aid in their everyday work. That represents a confirmation to the users of the business processes that the solution is serving its purpose. The following Tab. 4 presents the hired consulting companies for the implementation of SAP ERP solutions in the studied sample of companies in Serbia.

Table 4 Computer Consulting Company engaged in the implementation (by Research Survey ) [28]

\begin{tabular}{|l|c|}
\hline \multicolumn{1}{|c|}{ Company name } & $\begin{array}{c}\text { Engaged in consulting } \\
\text { companies }\end{array}$ \\
\hline Serbian Glass Factory AD & Atos Serbia/Bulgaria \\
\hline Swisslion Takovo & Aicon Serbia \\
\hline Holcim Serbia & B4B Serbia/Croatia \\
\hline JP PTT Serbia & S \& T Serbia \\
\hline Diamond Zrenjanin & S \& T Serbia \\
\hline
\end{tabular}

A very important factor in the introduction of the ERP system is active and functional communication between all involved in the project implementation ERP system. [34]. Communication itself means a formal progress and information concerning the progress of the project from the leadership of the project to other stakeholders in the organization. It is very important to have an adequate staff that must be chosen carefully. The teams working on the project plans for development and implementation of appropriate ERP solutions are typically diverse teams of staff by the bidder and the Employer. It is important that we have with both parties adequate interlocutors, who know the problems of the work. The following Fig. 4 shows the percentage of knowledge and communication between team members in the implementation of ERP solutions in Serbia.

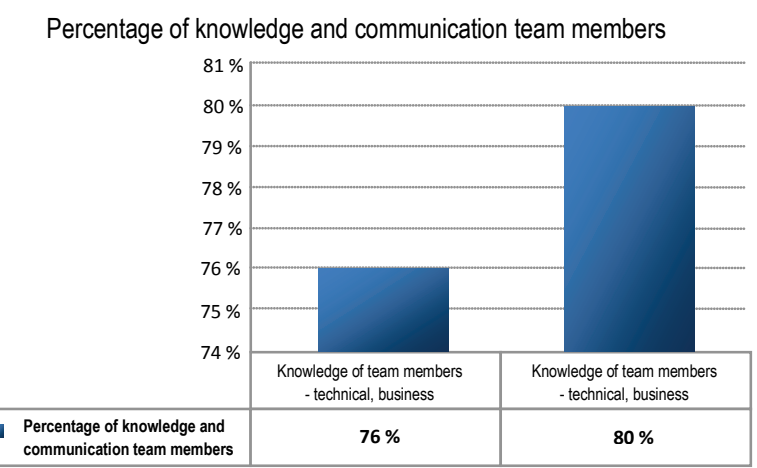

Figure 4 Percentage of knowledge and communication between team members during the implementation of ERP solutions in Serbia (according to a research survey) [28] 
The purpose of the study conducted in [33] is the definition of "critical failure factors", 47 of them, in order to help other industries, consultants and implementers to prevent failures during the ERP implementation. A number of projects of implementing ERP systems by hiring the wrong people get into trouble and difficulties. Therefore, there is a need for evaluation of the influence of ERP on the company's performance indicators. The project team must have adequate knowledge of the operations of the company, while all the members of the team must be creative and trained to accept a challenge to fight against the status quo, whenever it is needed. It is important that the project includes an appropriate number of personnel with adequate knowledge. Research indicates that companies will have, if they opt for information technology, to perform a wider range of tasks in the project. The leadership of that company management must control the project team and the project leader, and that is the only way for their decisions to be given an appropriate meaning and weight. Members of the team should be encouraged to make the key business decisions, and at the same time, the leadership should show the confidence and they must be lead to believe that they are not being controlled for every decision. Tab. 5 presents the critical success factors according to ASAP methodology of introduction in individual phases of ASAP methodology the rating is on a scale of 1 to 10 , smallest significance is 1 , and the greatest significance is 10. Research aims to examine the significance of the key success factors in the different stages of implementation in Serbian companies that have adopted SAP ERP solution.

Table 5 Significance of the critical success factors of the ASAP implementation phase (according to the research survey) [32]

\begin{tabular}{|c|c|c|c|c|c|c|c|c|}
\hline & & Critical Success Factors & Part 1 & Part 2 & Part 3 & Part 4 & Part 5 & Part 6 \\
\hline \multirow{15}{*}{ 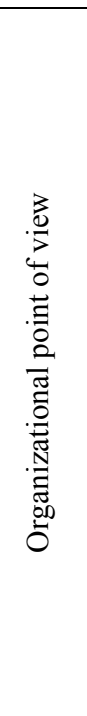 } & \multirow{8}{*}{ Strategically } & Support administration & 8 & 5 & 5 & 6 & 8 & 9 \\
\hline & & Changes in management & 6 & 9 & 6 & 5 & 6 & 7 \\
\hline & & Scope of management & 5 & 4 & 4 & 5 & 5 & 7 \\
\hline & & $\begin{array}{l}\text { The organization of the project } \\
\text { team and its jurisdiction }\end{array}$ & 5 & 4 & 4 & 4 & 4 & 4 \\
\hline & & $\begin{array}{l}\text { Re-engineering of business } \\
\text { processes }\end{array}$ & 4 & 7 & 4 & 4 & 5 & 5 \\
\hline & & Project Manager & 10 & 10 & 9 & 10 & 10 & 10 \\
\hline & & Participation of end-users & 5 & 8 & 10 & 7 & 5 & 10 \\
\hline & & Trust between partners & 5 & 8 & 10 & 7 & 5 & 8 \\
\hline & \multirow{7}{*}{ Tactical view } & $\begin{array}{l}\text { Commitment to Employees and } \\
\text { Consultants }\end{array}$ & 5 & 5 & 4 & 5 & 6 & 9 \\
\hline & & $\begin{array}{l}\text { Internal and external } \\
\text { communication }\end{array}$ & 7 & 7 & 5 & 6 & 8 & 10 \\
\hline & & The project plan & 9 & 7 & 7 & 7 & 5 & 5 \\
\hline & & Education Program & 5 & 5 & 5 & 7 & 4 & 5 \\
\hline & & Search and Troubleshooting & 4 & 4 & 7 & 9 & 7 & 7 \\
\hline & & Consultants & 5 & 4 & 4 & 4 & 4 & 5 \\
\hline & & Quick decisions & 3 & 5 & 5 & 5 & 4 & 4 \\
\hline \multirow{5}{*}{ 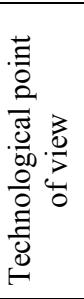 } & \multirow{3}{*}{ Strategically } & $\begin{array}{l}\text { Clear objectives, strategies and } \\
\text { scope of adopting ERP solutions }\end{array}$ & 5 & 4 & 4 & 4 & 4 & 4 \\
\hline & & Avoiding adjustment & 4 & 4 & 4 & 4 & 4 & 4 \\
\hline & & Different ERP solutions & 4 & 4 & 4 & 4 & 4 & 4 \\
\hline & \multirow[b]{2}{*}{ Technologically } & Customizing the software & 5 & 6 & 10 & 6 & 6 & 6 \\
\hline & & $\begin{array}{l}\text { Transfer data between ERP } \\
\text { solutions and existing information } \\
\text { systems }\end{array}$ & 3 & 4 & 4 & 4 & 4 & 4 \\
\hline
\end{tabular}

The introduction of a new ERP system is a great contribution to the restructuring and the establishment of a business system. For that normally we have only one option, which we need to take full advantage of, so that we have as much confidence as possible in a code of profession, which is based on practical experience. It is recommended that the project team involves the best people. As soon as the engagement of people in the project team does not show or is not seen in the daily operations of the company, we are confident that we have appointed the wrong people. Operating team members perform their tasks in the project during working hours, whenever it is possible. Performing emergency tasks on the project is also often very burdensome for the employees, because it is hard to concentrate on just one task, putting aside that the very quality of the work done is suffering. Let's try to distribute tasks to people who are not members of the project team. Incorporating people into the design team increases knowledge and understanding of each of its members, so that more members of the project team expand the ability to understand business processes in the enterprise. The help from these people at the end of the project is higher than it was prior to inclusion in the project. Experience indicates that it is necessary to use different strategies to further motivate team members. It often happens that the daily tasks are not completed until late in the evening. That is why it is necessary to find an additional way to motivate the team members, and is somehow connected with the policy of human resource management.

\section{Conclusion}

Project of implementation in the companies that were the subject of this studious research was followed by lack 
of the support from top management in some companies. It is these companies that were required to invest a lot of energy and work to motivate the customer to collect the necessary information, to participate in gathering the information about their current work with the old information system. Great job, that the users had to do, such as preparing data for transfer to the new system, was determined by consultants themselves or with the help of computer experts, who together with their painstaking, regular work, took the time to prepare data and other project activities. So the day was usually longer than 12 hours. Conversely, it is easy to speak of a support from the superiors in the project of introducing an information system in certain companies. Key users were further motivated to work on the project. Top level of the management, project team leaders and department leaders, had working meetings at which they discussed the progress of the project as well as the problems and solving them.

From the above study in specific companies we could put in the first place, as a key factor for the successful execution of the implementation of a new ERP solution or renewal of an information system, the resulting active support of the top leadership of the company. It certainly confirms such modern ERP solutions in the analysed companies, where despite the extremely short time of realization of the project (three months) and the complexity of the project, it was realized in due time, and the users have nevertheless adopted introduced ERP solution in the end.

This study has shown that the essence of the difficulty of the project of introducing ERP system, was represented by the selection of the strategy mode of introducing ERP system with adapting existing business process to standard, basic, functional solutions, helping the performance of implementation at a given time. Research in the companies indicates that in certain companies they have accessed the implementation of ERP solutions with tremendous customizing of ERP solutions, which, along with the improper conduct has led to exceeding the time of the introduction of information systems for more than two times.

The third most important factor for the success of the analyzed examples of companies is extensiveness of the enterprise to cover the functionality specific to each individual company. In some companies there was a good deal of interference in the core of the standard solutions. Research results impose it is itself the additional reason, that the weak guidance, and unpreparedness of the user for the project and testing lead a project to failure. In some companies, fortunately, number of such ventures was minimal, while some larger companies managed to avoid the same ventures. As for such a comprehensive undertaking the critical point is shortage of time, the consultants of the bidders have proposed purchase dubbed as "add-on" solution of local partners, who have been involved in these projects as subcontractors, as this standardized solution is integrated to the standard ERP solution in a fairly simple way.

\section{References}

[1] Davenport, T. Business Intelligence and Organizational Decisions. // International Journal of Business Intelligence Research. 1, 1(2010), pp. 1-12. DOI: 10.4018/jbir.2010071701

[2] Rouyendegh, B. D.; Baç, U.; Erkan, T. E. Sector selection for ERP implementation to achieve most impact on supply chain performance by using AHP-TOPSIS hybrid method. // Tehnički vjesnik-Technical Gazette. 21, 5(2014), pp. 933937.

[3] Loshin, D. Business intelligence: The savvy manager's Guide. Morgan Kaufmann Pub., 2012.

[4] Sykes, T. A.; Venkatesh, V.; Johnson, J. L. Enterprise System Implementation and Employee Job Performance: Understanding the Role of Advice Networks. // MIS Quarterly. 38, 1(2014), pp. 51-72.

[5] Feng Tian; Sean Xin Xu. How Do Enterprise Resource Planning Systems Affect Firm Risk? Post-Implementation Impact. // MIS Quarterly. 39, 1(2015), pp. 39-60.

[6] Mudiarasan Kuppusamy; Murali Raman; Bala Shanmugam; Santhapparaj Aruljeganathan Solucis. A Perspective on the Critical Success Factors for Information Systems Deployment in Islamic Financial Institutions. // The Electronic Journal of Information Systems in Developing Countries, (2009).

[7] Leyh, C. Which Factors Influence ERP Implementation Projects in Small and Medium-Sized Enterprises? // Proceedings of the $20^{\text {th }}$ Americas Conference on Information Systems, AMCIS 2014, August 7 - 9, Savannah - Georgia, USA, 2014.

[8] Nah, F.; Lau, J.; Kuang, J. Critical Factors for Successful implementation of Enterprise Systems. // Business Process Management Journal. 7, 3(2001), pp. 285-296. DOI: 10.1108/14637150110392782

[9] Lambeck, C.; Müller, R.; Fohrholz, C. \& Leyh, C. (Re-) Evaluating User Interface Aspects in ERP Systems - An Empirical User Study. // Proceedings of the $47^{\text {th }}$ Hawaii International Conference on System Science, HICSS 2014, January 6 - 9, Waikoloa, Big Island, Hawaii, USA, 2014, pp. 396-405.

[10] Chen, H.; Chiang, R. H. L.; Storey, V. C. Business Intelligence and Analytics: From Big Data to Big Impact. // MIS Quarterly. 36, 4(2012), pp. 1165-1188.

[11] Imhoff, C.; White, C. Self-Service Business Intelligence. // TDWI Best Practices Report. Third Quarter, 2011,

[12] Lahrmann, G.; Marx, F.; Winter, R.; and Wortmann, F. Business Intelligence Maturity: Development and Evaluation of a Theoretical Model. // In Proceedings of the $44^{\text {th }}$ Hawaii International Conference on System Sciences. 2011. DOI: $10.1109 /$ hicss. 2011.90

[13] Leyh, C. Critical Success Factors for ERP Projects in Small and Medium-sized Enterprises - The Perspective of Selected German SMEs. // Proceedings of the 2014 Federated Conference on Computer Science and Information Systems, FedCSIS 2014, September 6 - 10, Warsaw, Poland, 2014, pp. 1181-1190.

[14] Tsai, W.-H.; Lee, P.-L.; Shen, Y.-S.; Yang, C.-C. The relationship between ERP software selection criteria and ERP success. // Industrial Engineering and Engineering Management. IEEE International Conference 2009, pp. 2222-2226. DOI: 10.1109/ieem.2009.5373085

[15] Umble, M. M. (n.d.). Avoiding ERP implementation failure. http://www.allbusiness.com/management/1250601.html. (10.11.2010).

[16] Shaul, L.; Tauber, D. Critical success factors in enterprise resource planning systems. // Review of the last decade. ACM Computing Surveys (CSUR). 45, 4(2013), p. 55. DOI: $10.1145 / 2501654.2501669$ 
[17] Shaul, L.; Tauber, D. CSFs along ERP life-cycle in SMEs: a field study. // Industrial Management \& Data Systems. 112, 3(2012), pp. 360-384. DOI: 10.1108/02635571211210031

[18] Ghosh, S.; Skibniewski, M. J. Enterprise resource planning systems implementation as a complex project: a conceptual framework. // Journal of Business Economics and Management. 11, 4(2010), pp. 533-549. DOI: 10.3846/jbem.2010.26

[19] Grabski, S. V.; Leech, S. A.; Schmidt, P. J. A review of ERP research: A future agenda for accounting information systems. // Journal of Information Systems. 25, 1(2011), pp. 37-78. DOI: $10.2308 /$ jis.2011.25.1.37

[20] Chandler, N. Fast Forward to 2014 - Gartner Predicts the Future of Business Intelligence and Data Analytics. // TIBCO Spotfire's business intelligence blog. (2011). http://spotfireblog.tibco.com/?p=4779\#more-4779.

[21] Koh, S. L.; Gunasekaran, A.; Goodman, T. Drivers, barriers and critical success factors for ERPII implementation in supply chains: A critical analysis. // The Journal of Strategic Information Systems. 20, 4(2011), pp. 385-402. DOI: 10.1016/j.jsis.2011.07.001

[22] Yajun Zeng, et al. Risk assessment for enterprise resource planning (ERP) system implementations: a fault tree analysis approach. // Enterprise Information Systems. 7, 3(2013), pp. 332-353. DOI: 10.1080/17517575.2012.690049

[23] Foley, E.; Manon G. What is Business Intelligence? // International Journal of Business Intelligence Research. 1, 4(2010), pp. 1-28. DOI: 10.4018/jbir.2010100101

[24] Laursen, G. H. N.; Thorlund, J. Business Analytics for Managers: Taking Business Intelligence beyond Reporting. Wiley. La Valle, S., 2010.

[25] Mithas, S.; Ramasubbu, N.; Sambamurthy, V. How Information Management Capability Influences Firm Performance. // MIS Quarterly. 35, 1(2011), pp. 237-256.

[26] Somers, T. M.; Nelson, K. The impact of critical success factors across the stages of enterprise resource planning implementations. // IEEE Proceedings of the $34^{\text {th }}$ Hawaii International Conference On System Science, January, 2001, pp. 3-6.

[27] Denic, N.; Moracanin, V.; Milic, M.; Nešić, Z. Risk management in information system projects. // Tehnički vjesnik-Technical Gazette. 21, 6(2014), pp. 1239-1242.

[28] The company research. https: //www.idc.com /analysts/ analysthome.jsp. (01.04.2014).

[29] Esteves, J. M. An empirical identification and categorization of training best practices for ERP implementation projects. // Enterprise Information Systems. 8, 6(2014), pp. 665-683. DOI: 10.1080/17517575.2013.771411

[30] Shen, G. Unplugged to fix the disconnect between intelligence and analytics, we need an analytics-oriented BI architecture. // Information Management-Brookfield. 21, 1(2011), p. 14.

[31] Ralevic, P. V.; Dragojlovic, A.; Dobrodolac, M.; Denic, N. M.; Nešić, Z. Increasing organizational performance by human resource management. // Tehnički vjesnik-Technical Gazette. 22, 2(2015), pp. 236-239. DOI: 10.17559/tv20130905124436

[32] Amid, A.; Moalagh, M.; Ravasan, A. Z. Identification and classification of ERP critical failure factors in Iranian industries. // Information Systems. 37(2012), pp. 227- 237. DOI: 10.1016/j.is.2011.10.010

[33] Gajic, G.; Stankovski, S.; Ostojic, G.; Tesic, Z.; Miladinovic, $\mathrm{Lj}$. Method of evaluating the impact of ERP implementation critical success factors - a case study in oil and gas industries // Journal: Enterprise Information Systems. $8, \quad 1(2014), \quad$ pp. 84-106. DOl: 10.1080/17517575.2012.690105

[34] Vesic-Vasovic, J.; Radojicic, M.; Klarin, M.; SpasojevicBrkic, V. Multi-criteria approach to optimization of enterprise production programme. // Proceedings of the institution of mechanical engineers part B-Journal of engineering manufacture. 225, B10(2011), pp. 1951-1963. DOI: $10.1177 / 0954405410397433$

\section{Authors' addresses}

\section{Nebojsa Denic, PhD}

Faculty of Information Technology, Alfa University, Palmira Toljatija 3, 11000 Belgrade, Serbia

E-mail: denicnebojsa@gmail.com

\section{Vuk Vujovic, PhD candidate}

Faculty of Information Technology, Alfa University, Palmira Toljatija 3, 11000 Belgrade, Serbia

E-mail: vuk.mba.bg@gmail.com

\section{Vesna Stevanovic, PhD candidate}

Faculty of Information Technology, Alfa University, Palmira Toljatija 3, 11000 Belgrade, Serbia

E-mail: vesna.stevanovicpk@gmail.com

\section{Boban Spasic, PhD candidate}

Faculty of Information Technology, Alfa University, Palmira Toljatija 3, 11000 Belgrade, Serbia E-mail: bobanspasic11@gmail.com 